\title{
Anticipated and Repeated \\ Shocks in Liquid Markets
}

\author{
By \\ Dong Lou \\ Hongjun Yan \\ Jinfan Zhang \\ THE PAUL WOOLLEY CENTRE \\ WORKING PAPER SERIES NO 25 \\ FINANCIAL MARKETS GROUP \\ DISCUSSION PAPER NO 684
}

June 2011

Dong Lou has been teaching at the London School of Economics since July 2009. He earned his PhD in Finance from Yale University and a B.S. in Computer Science from Columbia University. His research mostly focuses on understanding market inefficiencies, and their distortionary effects on resource allocation in the real economy. Hongjun Yan is an Associate Professor of Finance at the Yale School of Management. He received his $\mathbf{P h D}$ from the London Business School in 2005. The focus of his current research is to better understand the behaviour of asset prices by incorporating bounded rationality, heterogeneous beliefs, reputation, learning and market imperfections etc. into standard asset pricing framework. Jinfan Zhang is currently a PhD candidate in Finance from Yale University. He earned his PhD and B.S. both in Electrical Engineering from Tsinghua University (China). Zhang's research mostly focuses on the institutional origins of asset market liquidity and its impact on asset pricing and financial crisis. Any opinions expressed here are those of the authors and not necessarily those of the FMG. The research findings reported in this paper are the result of the independent research of the authors and do not necessarily reflect the views of the LSE. 


\title{
Anticipated and Repeated Shocks in Liquid Markets*
}

\author{
Dong Lou \\ London School of Economics \\ d.lou@lse.ac.uk \\ Hongjun Yan \\ Yale School of Management \\ hongjun.yan@yale.edu \\ Jinfan Zhang \\ Yale School of Management \\ jinfan.zhang@yale.edu
}

This Draft: June 15, 2011

\footnotetext{
* We thank Viral Acharya, Nick Barberis, Mikhail Chernov, Greg Duffee, Darrell Duffie, Michael Fleming, David Goldreich, Robin Greenwood, Peter Kondor, Arvind Krishnamurthy, Andrew Metrick, Lasse Pedersen, Christopher Polk, Tyrone Smith, Jeremy Stein, Dimitri Vayanos, Lei Xie, Tong Yu, and seminar participants at UC Irvine, LSE, Yale, and Econometric Society Meetings for helpful comments. We are also grateful to Pengjie Gao, Andrea Vedolin, and Tong Yu for their generous help with some of the data used in this paper. Lou acknowledges financial support from the Paul Woolley center at the London School of Economics. Yan received support from a Whitebox Advisors research grant administered through the Yale International Center for Finance. Please direct all correspondence to Hongjun Yan.
} 


\title{
Anticipated and Repeated Shocks in Liquid Markets
}

\begin{abstract}
We show that Treasury security prices in the secondary market decrease significantly before subsequent auctions and recover shortly after. This price pattern implies a large issuance cost for the Treasury Department, which is estimated to be between 9 and 18 basis points of the auction size. For example, this cost amounts to over half a billion dollars for issuing Treasury notes alone in 2007. Our results appear to be consistent with the hypothesis of primary dealers' limited risk-bearing capacity and the imperfect capital mobility of end investors in the Treasury market (e.g., federal agencies, sovereign wealth funds, pension funds, and etc.), highlighting the important role of capital mobility even in the most liquid financial markets.
\end{abstract}

JEL Classification Numbers: G12.

Keywords: Liquidity, Slow-moving capital, Supply shocks, Treasury auctions. 


\section{Introduction}

In this paper, we empirically examine how anticipated and frequently repeated supply shocks are absorbed in liquid financial markets. In particular, we examine the temporary price impacts of Treasury security auctions on the secondary Treasury, repo, and equity markets. This may appear as a surprising agenda: Treasury auctions are conducted every month, of which the exact dates and amounts are announced in advance, so these events are largely anticipated; in addition, Treasury auctions are usually accompanied by the maturity of similar Treasury securities, so the net supply effect is likely small. Given the size and liquidity of the U.S. Treasury, repo, and equity markets, one might expect no appreciable price impacts from these anticipated events. ${ }^{1}$ In sharp contrast to this conventional view, our evidence reveals significant temporary price effects in all three markets around Treasury auctions.

Specifically, we find that Treasury auctions exert significant price pressure in the secondary Treasury market during the 5 to 10 days leading up to these auctions and that this price pressure gradually dissipates in the subsequent 5 to 10 days. An intuitive way to describe this price dip and recovery pattern is to compare Treasury returns around auctions: For example, the 5-day cumulative return of the on-the-run 2-year Treasury note before the subsequent 2-year note auction is, on average, $8.89(t=2.93)$ basis points lower than the 5-day post-auction return of the same security. ${ }^{2}$ Similarly, this 5-day return differential is, on average, $22.54(t=3.67)$ basis points for 5-year notes around subsequent 5-year note auctions, and $23.84(t=1.78)$ basis points for 10-year notes around subsequent 10-year note auctions.

These findings have important economic implications. First of all, they suggest that the cost of security issuance borne by the Treasury Department is an order of magnitude larger than auction markups estimated in prior literature, which compares

\footnotetext{
${ }^{1}$ In 2008, the total size of Treasury securities outstanding is $\$ 10$ trillion (from Treasury Department website), the total U.S. stock market capitalization is $\$ 14$ trillion (from CRSP), and the estimated size of the repo market is over $\$ 10$ trillion (Gorton and Metrick (2010)).

${ }^{2}$ An on-the-run Treasury security is the most recently issued security of a given maturity. The first offthe-run and the second off-the-run securities are the second and third most recently issued securities of a given maturity, respectively.
} 
the auction price with a benchmark price on the auction day, and often finds the markup to be around 1 basis point of the auction size. ${ }^{3}$ Our findings suggest that, because of the price impact of Treasury auctions, these benchmark prices on auction days are already depressed. Therefore, while the traditional approach is appropriate for measuring auction underpricing, it does not reflect the total issuance cost borne by the Treasury Department.

To incorporate price impacts into our cost measure, we take the average price in the secondary Treasury market on the $t^{\text {th }}$ day before and the $t^{\text {th }}$ day after each auction as the benchmark price, with $t$ ranging from 1 to $10 .^{4}$ That is, our measure reflects the amount of money the Treasury Department could have saved were it able to issue Treasury securities at the secondary market prices several days before and after auctions. For $t=5$, for example, our estimates of Treasury issuance costs for 2-, 5-, and 10-year notes are 9.07, 16.81, and 18.43 basis points of the auction size, respectively. According to these estimates, the total cost of issuing Treasury notes alone in 2007 is $\$ 643$ million. This cost is likely to be substantially higher in the near future when the U.S. government faces an unprecedented budget deficit. While it is by no means clear whether part of the estimated cost can be saved through better designs of the Treasury selling mechanism, recognizing such a cost is a necessary first step to understand and improve its efficiency. ${ }^{5}$

Second, our findings suggest that the frictions behind investors' slow responses to demand/supply shocks are of first-order importance even in the most liquid financial markets. A simple long-short strategy that exploits these large and reoccurring swings in Treasury returns around auction days yields a Sharpe ratio that is higher than many well-known asset pricing anomalies, such as currency carry trades and price momentum. For example, by going short in the on-the-run 2-year note and long in a duration-

\footnotetext{
${ }^{3}$ See, for example, Nyborg and Sundaresan (1996) and Goldreich (2007).

${ }^{4}$ This is likely a conservative estimate since the auctioned security will become "on-the-run" in a few days and should be worth more than the soon-to-become-off-the-run note, as suggested by the well-known onthe-run-off-the-run phenomenon (e.g., Amihud and Mendelson (1991), Krishnamurthy (2002)).

${ }^{5}$ Motivated by our empirical evidence, Jin and Yan (2011) analyze a model of optimal security selling mechanism when capital is slow-moving.
} 
matched portfolio comprising the on-the-run 6-month Treasury bill and 10-year note during the 10 days before each 2-year note auction, and holding reversed positions during the 10 days after, an investor can achieve an annualized Sharpe ratio of 1.08. In comparison, the Sharpe ratios are around 0.59-0.95 for currency carry trades, and 0.470.75 for price momentum strategies in the U.S. stock market. ${ }^{6}$ These results also hold in the more recent period when trading costs in the Treasury market are minimal. For example, in the period of 1998-2008, the Sharpe ratio of our strategy is 1.44; even after accounting for the bid-ask spread, it remains close to 1. Moreover, the documented return pattern implies large swings in bond premium around auction days each month. Even our most conservative estimate implies that the post-auction annualized bond premium is $2.3 \%$ higher than its pre-auction counterpart. This difference is economically significant given that the unconditional bond premium is only $1.4 \%$ in our sample, thus posing a big challenge for asset pricing models.

Finally, the shocks analyzed here are small relative to the size of Treasury markets. In the last 10 years, the average auction size of Treasury notes is merely $0.3 \%$ of the Treasury market size. ${ }^{7}$ If one takes into account the amount of Treasury securities maturing in each month, the net supply shock is even smaller. In addition, the timing and size of Treasury auctions are announced in advance, making Treasury auctions a clean setting to analyze temporary price effects of supply shocks. Our evidence that markets are unable to quickly absorb these anticipated small shocks, repeatedly, suggests that capital mobility is perhaps more limited than previously thought, even in the most developed financial market. ${ }^{8}$ It is thus reasonable to expect that similar effects play an even bigger role in less liquid markets, such as corporate bond and structured product markets.

\footnotetext{
${ }^{6}$ See, e.g., Brunnermeir, Nagel, and Pedersen (2009), Lustig, Roussanov, and Verdelhan (2009), Asness, Moskowitz, and Pedersen (2008), and Burnside, Eichenbaum, Kleshchelski, and Rebelo (2010).

${ }^{7}$ In contrast, the demand shocks analyzed in Shleifer (1986) are close to $3 \%$ of the shares outstanding.

${ }^{8}$ In a recent study, Fleckenstein, Longstaff, and Lustig (2010) provide another piece of evidence on the imperfection of the Treasury markets: Nominal Treasury bonds are significantly underpriced relative to a portfolio of TIPS and inflation swaps.
} 
The documented return pattern is consistent with two factors working in the Treasury market. ${ }^{9}$ First, primary dealers, who are required to participate actively and to submit competitive bids in all Treasury auctions, have limited risk-bearing capacity. ${ }^{10}$ They hence hedge part of the risk they are about to acquire in Treasury auctions by short selling the same or similar securities in the secondary market before these auctions. For example, Fleming and Rosenberg (2007) show that primary dealers take short positions in both the secondary Treasury market and when-issued market before Treasury auctions. ${ }^{11}$ Consistent with this interpretation, we find that the price impact in the secondary Treasury market is more pronounced precisely when the total risk to be acquired by primary dealers is larger; for instance, when the auction size is larger and when Treasury returns are more volatile (as implied by options on Treasury securities).

The limited risk bearing capacity of primary dealers alone, however, is unable to explain the whole phenomenon: Primary dealers' short selling in secondary Treasury markets would not have a price impact, were there enough arbitrage capital or endinvestors to supply liquidity. It should not come as a surprise that arbitrage capital is likely insufficient to absorb the entire supply due to Treasury auctions, which is in the magnitude of tens of billions of dollars. Yet for primary dealers' shorting to have a material price impact, we must also have end-investors' capital be slow-moving. This point is particularly important since a large amount - sometimes even larger than the

\footnotetext{
${ }^{9}$ An alternative interpretation is that Treasury auctions have information contents. Although Treasury auctions are fully anticipated, their outcomes are likely to contain information about economic conditions. However, if uncertainty about these auctions is resolved gradually in the days leading up to these auctions, the pre-auction Treasury returns should be higher than post-auction ones, opposite to our findings.

${ }^{10}$ According to Administration of Relationships with Primary Dealers, available from the website of the Federal Reserve Bank of New York, http://www.ny.frb.org/markets/pridealers_policies.html, "Primary dealers are also required to participate in all auctions of U.S. government debt and to make reasonable markets for the New York Fed when it transacts on behalf of its foreign official account-holders." According to Fleming (2007), primary dealers alone purchased $70.9 \%$ of Treasury securities sold to the public (and another $21.6 \%$ on behalf of their institutional clients) during July 30, 2001 to December 28, 2005.

${ }^{11}$ Fleming and Rosenberg (2007) also find a price increase in the week subsequent to the auction, and interpret the price appreciation as a compensation for dealers' bearing the risk associated with their inventory changes.
} 
offering amount - of Treasury securities are maturing around these auctions - i.e., end investors do have enough capital to absorb the supply. ${ }^{12}$

Major investors in Treasury markets are indeed likely unresponsive to transient demand/supply shocks. Although the total size of Treasury securities outstanding is around $\$ 10$ trillion, over $40 \%$ of them are nonmarketable and held by Federal Government accounts. ${ }^{13}$ The Federal Reserve holds another $8 \%$ to $9 \%$, most of which is obtained through noncompetitive bids at auctions. "Private holdings" constitute the rest, of which foreign investors and state and local governments account for more than half. While there are no publicly available data on these public or private holdings, it seems reasonable to expect that many of them do not have the intention, or resources, to engage in short-term arbitrage trades. In addition, insurance companies and bond mutual funds, which account for around $13 \%$ of private holdings, are also likely to be unresponsive to the temporary price movements around auctions. For example, we find $70 \%$ of the insurance companies in the U.S. make less than 5 trades a year in Treasury markets. Index bond mutual funds, due to concerns of tracking errors, are likely to avoid newly issued securities before they are included in the indices they are tracking. ${ }^{14}$

Our interpretation has a number of further predictions. First, it implies that repo rates tend to be lower before auctions. To take short positions in the secondary Treasury market, primary dealers need to borrow Treasury securities, which is often fulfilled through "reverse repo" transactions. In these transactions, primary dealers effectively lend to their counterparties and take Treasury securities as collateral, which they then short-sell in secondary markets. Primary dealers' strong demand for these transactions implies that they would be willing to accept lower interest rates on their lending, thus leading to lower repo rates before auctions. Since this hedging activity is expected to last only for a few days, its impact should be stronger for overnight repo

\footnotetext{
${ }^{12}$ For example, on June 1, 2004, the Treasury Department issued around $\$ 25$ billion 2-year notes, but there were $\$ 27$ billion worth of Treasury securities maturing on the previous day.

${ }^{13}$ The data on the ownership of Treasury securities are from http://fms.treas.gov/bulletin/index.html.

${ }^{14}$ Many fixed-income indices usually adjust their composition at the end of each month. For example, Barclays US Treasury Bond Index adjusts its composition on the last calendar day of each month; see, https://ecommerce.barcap.com/indices.
} 
rates than for long-term repo rates. Consistent with this conjecture, we find that the average overnight general-collateral repo rates during the 5 days before 2-year note auctions is $6.75(t=4.83)$ basis points lower than that during the 5 days after. The pattern for one-week term repo rates is slightly weaker, with a rate differential of 4.39 $(t=4.36)$ basis points, while that for one-month repo rates is virtually absent.

Second, since off-the-run notes are close substitutes to on-the-run ones, our interpretation implies that the price impact around auctions should also arise for offthe-run securities. Indeed, we find that the return pattern of off-the-run notes is almost identical to that of on-the-run notes. Third, auctions of Treasury securities with one maturity should also affect prices of other maturities, and the impact should be stronger if the maturity differential is smaller. Consistent with this prediction, we find a similar price pattern of 10-year notes around both 2-year and 5-year note auctions, even when there is no 10-year note auction in surrounding days. Moreover, relative to 2-year note auctions, 5-year note auctions have a much stronger price impact on 10-year notes.

Finally, since Treasury yields affect the discount and borrowing rates in other financial markets, one might expect the Treasury yield movements documented in this paper to also affect prices in other markets, such as the equity market. To our surprise, we find very large equity price movements around Treasury auctions: The average cumulative return of the value-weighted CRSP index in the 5 days before 2-year note auctions is $49(t=3.11)$ basis points lower than that after these auctions. Put differently, in the past three decades, the average stock market return is negative during the 5 days before 2-year note auctions, and is more than twice the unconditional average during the 5 days after. We further show that this return pattern is not driven by calendartime effects (e.g., the turn-of-the week, turn-of-the-month, and turn-of-the-year effects). While the stock return pattern is broadly consistent with our interpretation, the exact underlying mechanism for such a large price impact remains unclear.

The rest of the paper is organized as follows: Section II reviews the related literature and Section III describes the data. Section IV analyzes the impacts of Treasury auctions on the secondary Treasury market. Section V presents the 
interpretation and further analysis implied by the interpretation. Sections VI and VII analyze the impact on the repo and stock markets, respectively. Section VIII concludes.

\section{Related Literature}

Our paper is closely related to the growing literature on the temporary price impact of supply/demand shocks in financial markets. Since the seminal paper by Shleifer (1986), there has been a proliferation of research examining the effect of uninformed demand shocks on stock returns. For example, Kaul, Mehrotra, and Morck (2000), Wurgler and Zhuravskaya (2002), Mitchell, Pulvino, and Stafford (2004), Greenwood (2005), Coval and Stafford (2007), Frazzini and Lamont (2008), and Lou (2010) analyze the temporary price effects of index additions/deletions, short-selling induced by mergers and acquisitions, and mutual fund flow-induced trading in the stock market. The contribution of our paper lies in that we provide evidence for temporary price pressure in a cleaner setting where the small supply shocks that we analyze are both well anticipated and frequently repeated. This unique feature helps highlight the first-order importance of market frictions to our understanding of asset price formation and evolution.

Our results also complement prior research on the supply effect in the Treasury market. One strand of this research examines the level effect. For example, Simon (1991, 1994), Duffee (1996), Fleming (2002), Krishnamurthy (2002), Kuttner (2006), Greenwood and Vayanos (2010a), and Krishnamurthy and Vissing-Jorgensen (2010) document a positive correlation between the (residual) supply of individual Treasury securities and their idiosyncratic yields. Another strand of research in this literature analyzes the supply effect by looking at changes in Treasury yields around various policy announcements. For example, Garbade and Rutherford (2007), Gagnon, Raskin, Remache and Sack (2010), Greenwood and Vayanos (2010b), D'Amico and King (2011), Krishnamurthy and Vissing-Jorgensen (2011), and Swanson (2011) report significant drops in Treasury yields on announcements of large buy-back programs initiated by the Treasury and Federal Reserve. Our paper differs from these prior studies in that it 
examines Treasury auctions' temporary price impact in the secondary Treasury markets, both before and after auctions taking place, as well as their spillover effects across maturities and across markets. ${ }^{15}$

Our results are generally consistent with the market segmentation view modeled in Vayanos and Vila (2009). Preferred-habitat investors cause market segmentation and make local demand and supply, in our particular case, the short-selling by primary dealers, matter for idiosyncratic Treasury yields. Arbitrageurs, in the meanwhile, take away part of the profits and maintain a smooth yield curve, but are constrained by their risk/capital capacity. End investors (e.g., federal agencies, sovereign wealth funds, pension funds, and etc.), who have sufficient capital to absorb the supply, are slow in responding to these shocks. As a result, part of the price effect remains in the data.

Finally, our results highlight the key role of not only primary dealers' and arbitrageurs' limited risk-bearing capacity, but more importantly, end-investors' slowmoving capital. Hence, our study contributes to the recent theoretical literature that starts to incorporate limitations in capital mobility to asset pricing models (e.g., Acharya, Shin, and Yorulmazer (2009), He and Xiong (2009), Duffie (2010), Malliaris and Yan (2010)).

\section{Data}

\section{A. Institutional background of Treasury auctions}

In our sample period of 1980-2008, the U.S. Treasury Department auctioned, on average, $\$ 2.35$ trillion worth of securities each year; the total amount auctioned was $\$ 6.7$ trillion in 2008. The participants of these auctions include primary dealers, institutional investors, foreign central banks, the Federal Reserve, and a small number of individual investors. The Treasury Department usually schedules the auction dates several months

\footnotetext{
${ }^{15}$ D'Amico and King (2011) also analyze Treasury yield changes on the days when purchase operations by the Federal Reserve actually occur, and document a temporary price increase that is largely reversed on the following day. However, they focus on a specific, short, period of time, from March to October 2009, when the quantitative easing program (QE1) took place.
} 
in advance and announces the auction size several days before each auction. Immediately after the announcement, dealers and investors in the Treasury market start to trade forward contracts on the soon-to-be-issued Treasury security in the "whenissued" market.

In each auction, primary dealers and other competitive bidders submit sealed bids of rate-quantity pairs that specify the amount to be purchased at each minimum yield. Two auction mechanisms have been employed in Treasury auctions: multiple-price and single-price auctions. Under both mechanisms, the clearing price is identified by equating the aggregate demand submitted by competitive bidders to the total issue amount minus the total demand from noncompetitive bidders (i.e., those who submit market orders). The difference between the two mechanisms lies in that, while in multiple-price auctions, competitive bidders pay for their allocated shares at their submitted rates, in single-price auctions, all winning bidders pay the same price. While almost all Treasury auctions in the 1980s were multiple-price auctions, the single-price mechanism is the dominant form in the more recent two decades. ${ }^{16}$

\section{B. Data sample}

From the U.S. Treasury Department website, we collect detailed information regarding individual auctions for Treasury notes, with maturities ranging from 2 to 10 years. Such information includes the auction date, issue date, auction mechanism, bids submitted, total tender amount received, total tender amount accepted, lowest and highest winning rates, etc. Our sample spans from January 1980 to June 2008, during which period 2year Treasury notes are issued on a monthly basis and 10-year notes are issued on a quarterly basis. The issuing frequency of 5-year notes varied a few times in this period. In total, we have 332 2-year note auctions, 210 5-year note auctions, and 132 10-year note auctions. ${ }^{17}$ We then match our auction data with the CRSP daily U.S. Treasury database to obtain daily Treasury security prices and carried interests. Throughout our

\footnotetext{
${ }^{16}$ For more detailed discussions of these two auction mechanisms see, e.g., Goldreich (2007).

${ }^{17}$ The Treasury also issued 3-, 4-, and 7-year notes roughly at a quarterly frequency. Their issuance, however, was interrupted in the period of 1998-2003 for 3-year notes, 1990-2008 for 4-year notes, and 1993-2008 for 7-year notes.
} 
analysis, we use the average of the bid and ask prices from CRSP as our measure of clean prices.

We supplement our Treasury auction and yield data with five additional data sources. First, we obtain daily repo rates from Bloomberg. Second, to examine insurance companies' trading activities in Treasury markets, we get their trading records from their annual reports to National Association of Insurance Commissioners (NAIC). In particular, Schedule D of these reports includes trades by insurance companies in each year and their holdings at the end of the year. ${ }^{18}$ Third, we obtain daily stock returns from the CRSP daily stock files. Fourth, we collect from TrimTabs, for the period of 1998-2008, daily investment flows to three major mutual fund classes: bond mutual funds, equity funds, and hybrid funds. Finally, from Mueller, Vedolin, and Yen (2011), we obtain the daily model-free estimates of maturity-weighted implied volatility of nearest-to-expiry at-the-money options on the 30-year, 10-year, and 5-year Treasury securities.

Table I presents some descriptive statistics of our sample. Panel A reports the summary statistics associated with Treasury auctions, and Panels B and C report those for all other main variables. The average size of Treasury auctions across all maturities is well over $\$ 10$ billion. The average daily Treasury note return ranges from 1.96 (for 2year notes) to 2.31 (for 10-year notes) basis points. The average daily return of the value- and equal-weighted CRSP indices and the value-weighted S\&P 500 index are 4.45, 8.15, and 3.53 basis points, respectively. The average daily flows to bond, equity, and hybrid mutual funds reported by TrimTabs are $0.4,-0.92$, and -0.19 basis points per day. ${ }^{19}$ Finally, the average maturity-weighted Treasury-auction implied volatility is around $8 \%$ in our sample.

\footnotetext{
${ }^{18}$ See Jiang, Yan, and Yu (2010) for detailed descriptions of this dataset.

${ }^{19}$ See Edelen and Warner (2001) and Greene and Hodges (2002) for a description of the construction of flows and its potential issues.
} 


\section{Price Impact on Secondary Markets}

To analyze the impact of Treasury auctions on the secondary Treasury market, we first examine yields-to-maturity of 2-year notes, the most frequently issued Treasury notes, around subsequent 2-year note auctions. Specifically, for each 2-year note auction, we calculate daily yields to maturity of the on-the-run 2-year note during both the 10 days before and 10 days after the auction and compare them with the yield on the auction day. ${ }^{20}$ Since there is a 2-year note auction almost every month in our sample, these 20day event windows around auctions cover virtually all trading days in our sample period.

The pattern in Treasury yields around auctions can be easily seen in Figure 1. The upper-left panel plots the time series average of $\mathrm{Y}(t)-\mathrm{Y}(0)$, where $\mathrm{Y}(t)$ is the yield of the on-the-run 2-year note on day $t$ and $\mathrm{Y}(0)$ is the yield of the same security on the auction day. There is a clear inverted- $\mathrm{V}$ shaped pattern: yields tend to go up before auctions and then decrease afterward. More detailed results are presented in Table II: The yield differences, $\mathrm{Y}(t)-\mathrm{Y}(0)$, are negative in the entire 20-day event window surrounding each auction, and are statistically significant in the 4 days immediately before the auctions and 6 days after the auctions. More specifically, the yield of 2-year notes increases, on average, by 2.53 basis points during the 5-day period before the auctions, but decreases by 2.32 basis points during the 5 -day period afterward.

These results suggest that 2-year note auctions exert temporary price pressure on the existing 2-year notes; secondary market prices are lower on auction days than in surrounding days. Another way to see this price impact is to compare 2-year note returns before and after these auctions. This approach effectively integrates the pre- and post-auction impacts into one measure and so increases the statistical power in detecting such price impact. As shown in Table III, the return of the on-the-run 2-year note on the day prior to the subsequent auction is, on average, 3.68 basis points lower than the return of the same note on the day immediately after the auction, with a $t$-statistic of 3.90. The return difference is positive and statistically significant in the entire 20-day window: The average cumulative return during the 10 days after auctions is 9.20 basis

\footnotetext{
${ }^{20}$ We track the same 2-year note throughout the 20-day window around each auction, even though this security becomes off-the-run immediately after the auction.
} 
points higher than that during the 10 days before, with a $t$-statistic of 2.02 . The return differential achieves its maximum on day 6 , with a point estimate of 10.2 basis points and a $t$-statistic of 3.62 .

The documented yield and return pattern around subsequent auctions is not unique to 2-year notes. A very similar pattern exists for other maturities. For example, as shown in Table II, the yield of the on-the-run 5-/10-year notes increases by $2.67 / 1.57$ basis points during the 5 days before auctions, and decreases by $2.73 / 2.00$ basis points in the 5 days after. Moreover, as shown in Table III, the cumulative 5 -day return of the on-the-run 5-year Treasury note before a 5-year note auction is, on average, 22.54 $(t=3.67)$ basis points lower than the 5 -day return of the same note after the auction. This return difference is $23.84(t=1.78)$ basis points for 10 -year notes.

\section{A. Economic significance}

The temporary movements in Treasury yields around subsequent auctions have a number of important implications. First, they represent a substantial issuance cost borne by the Treasury Department, which has been largely ignored in prior literature. Second, they imply a potentially large trading profit, even after taking into account transaction costs. Finally, these large swings in average Treasury returns provide useful guidance for future asset-pricing models. We examine these issues in more detail in this section.

\section{A.1. Large issuance costs}

In prior literature, Treasury auction markups are usually measured as the difference between the auction price and some benchmark traded price on auction days (e.g., the secondary market price or the forward price in the when-issue market). While this is perhaps a clean measure of auction underpricing due to winner's curse, it does not reflect the total cost borne by the Treasury Department, as our previous results suggest that the secondary market prices on auction days have already been driven down by these auctions.

To take into account the price pressure effect resulting from Treasury auctions, we take as the benchmark price the average secondary Treasury market prices around 
each auction (rather than on the auction day). We then calculate the amount of money the Treasury Department could have saved were it able to issue Treasury notes at this benchmark price. We note that this is likely a conservative estimate since the auctioned security will become "on-the-run" in several days and should be worth more than the soon-to-be-off-the-run security in the secondary market, as suggested by the well-known on-the-run-off-the-run phenomenon (e.g., Amihud and Mendelson (1991), Krishnamurthy (2002)). Table IV shows that Treasury issues notes at yields that are significantly higher than those in the secondary market. Panel A reports $Y(A)-\bar{Y}(t)$, where $Y(A)$ is the auction yield and $\bar{Y}(t)$ is the average of the on-the-run note yields on the $t^{\text {th }}$ day before and $t^{\text {th }}$ day after the auction, with $t$ ranging from 1 to 10 . The results suggest that auction yields are significantly higher than yields in the secondary market around auctions. Take 2-year notes, for example: the yield difference measure, $Y(A)-$ $\bar{Y}(t)$, for $t=1,5$, and 10 are $3.63(t=5.77), 4.90(t=4.62)$, and $5.05(t=3.42)$ basis points, respectively. The results are similar for 5 - and 10 -year notes. For $t$ equal to 5 , the yield difference is $4.04(t=4.70)$ basis points for 5 -year notes and $2.66(t=3.12)$ basis points for 10-year notes.

Based on these yield differences, we further compute the implied cost borne by the Treasury Department both as a fraction of total issuance size and in dollar terms. As shown in Panel B, based on the yield difference for $\mathrm{t}=5$, the issuance costs for 2-, 5-, and 10- year notes are 9.07, 16.81, and 18.43 basis points of the auction size, respectively. These figures translate into large dollar amounts. For 2007, the last full year in our sample, the implied total cost of issuing Treasury notes amounts to $\$ 649$ million. Based on the yield difference $Y(A)-\bar{Y}(t)$, for $t \geq 8$, the implied costs are well above $\$ 700$ million.

While it is by no means clear how part of the above estimated issuance cost can be saved through better designs of the Treasury issuance mechanism, recognizing this cost is undoubtedly an essential first step to assess and improve the efficiency of the mechanism. Motivated by our empirical results, Jin and Yan (2011) analyze a model of security issuance when issuance has a price impact in the secondary market. In 
particular, they analyze the potential benefits and costs when the seller increases the frequency of auctions and hence reduce the lumpiness of the supply shocks.

\section{A.2. Trading profits}

The documented return pattern around Treasury auctions also implies potentially large trading profits. For example, to take advantage of the price movements around 2-year note auctions that happen almost every month in our sample, one can short the on-therun 2-year note in the $t$ days before each auction, and long a duration-matched portfolio comprising the on-the-run 6-month T-bill and 10-year note to hedge out the interest rate risk. Then one can switch to the reversed positions, long the 2-year note and short the 6-month bill and 10-year note, in the $t$ days after the auction. As shown in Table V, this simple long-short portfolio generates significant profits. Panel A reports the results based on the full sample. The portfolio return is significant and positive for all $t$ ranging from 1 to 10, with 9 out of the 10 return estimates being significant at the $1 \%$ level. For $t=10$, for instance, the average return of this trading strategy is $8.62(t=3.65)$ basis points, with an annualized Sharpe ratio of 1.08. For reference, the Sharpe ratios for currency carry trades and stock price momentum are around 0.59-0.95 and 0.47-0.75, respectively (see, e.g., Brunnermeir, Nagel, and Pedersen (2009), Lustig, Roussanov, and Verdelhan (2009) and Asness, Moskowitz, and Pedersen (2008)).

The strategy requires large turnover: one needs to complete two "round trips" each month for both their long and short positions, and hence to pay twice the bid-ask spreads. To examine whether transaction costs have a material impact on the documented trading profits, we start by exploiting time-series variations in bid-ask spreads in our sample period. We estimate from the CRSP dataset that the average bidask spread for 2-year on-the-run notes drops from 9 basis points in the first 10 years of our sample to 1.7 basis points in the last 10 years, a general trend consistent with prior evidence based on various data sources (e.g., Amihud and Mendelson (1991), Jegadeesh (1993), Fleming (2003)). If trading costs play a significant role in explaining our return pattern, we would expect to observe a decreasing trend in the profitability of this strategy. However, as shown in Panel B of Table V, the average returns to our simple strategy in the last 10 years of the sample are similar in economic magnitude to those 
based on the full sample, and with a much higher Sharpe ratio. Take $t=10$, for example: the annualized Sharpe ratio of the strategy in the last 10 years is 1.44 , compared with 1.08 achieved in the full sample.

To more directly assess the Sharpe ratio net of transaction costs, we take bid-ask spread estimates from Fleming (2003), who calculates daily interdealer bid-ask spreads for on-the-run Treasury securities using firm/market quotes from GovPX for the period of December 1996 to March 2000. ${ }^{21}$ Based on these estimates, the overall bid-ask spread for our long-short portfolio is 1.46 basis points. ${ }^{22}$ Since our trading strategy requires two round trips each month, the total transaction cost is $35.04(=1.46 \times 2 \times 12)$ basis points per year. In other words, after taking into account transaction costs, the Sharpe ratio of the strategy is still as high as 0.95 during the last 10 years of our sample.

\section{A.3. Implications for theoretical models}

The large Sharpe ratio of our trading strategy calls for a search for additional risk factors that the strategy may be exposed to and, perhaps more likely, the trading frictions beyond bid-ask spreads (e.g., the cost of shorting Treasury securities) that may prevent arbitrageurs from exploiting this opportunity.

Moreover, the large swings in Treasury returns between the pre- and post-auction periods pose a significant challenge to asset-pricing models. Our most conservative estimate, based on the entire 20-day window around each auction, implies an increase in annualized expected 2-year note return by $2.3 \%$ from the pre-auction to post-auction period. For reference, the average 2-year note return premium (over 3-month T-bill returns) is $1.4 \%$ in our sample. This result is hard to explain by existing asset-pricing theories, especially given the recurring nature of this phenomenon.

\footnotetext{
${ }^{21}$ It has been noticed that the CRSP indicative bid-ask spread data has various problems, especially for the early sample period (see, e.g., Duffee (1996)).

${ }^{22}$ Fleming (2003) shows that the average bid-ask spreads for 10-year, 2-year, and 6-month Treasury securities are 2.44, 0.66, and 0.37 basis points, respectively. According to our duration estimates, the hedge portfolio has $20 \%$ in 10-year notes and $80 \%$ in 6 -month T-bills. Thus the bid-ask spread for the whole portfolio is $0.66+2.44 \times 0.2+0.37 \times 0.8=1.46$ basis points.
} 


\section{B. Robustness}

The phenomenon documented here is not unique to on-the-run securities. As shown in the lower row of Figure 1, the yield pattern for off-the-run notes is almost the same as that for the on-the-run securities. We repeated the analysis in Tables II and III for offthe-run notes and get very similar results. We also conduct a number of additional tests to examine the robustness of our results. First, we repeat our analysis on three subsamples: 1980-1990, 1991-2000, and 2001-2008. The main results hold for all subsamples and appear to be stronger for the more recent two decades. Second, since auctions usually take place in the middle of a day, it is unclear whether the return on the auction day itself should be classified as pre-auction or post-auction. We repeat our analysis by excluding auction day returns and the results are by and large unchanged. Finally, since Treasury securities accumulate interest payments on each calendar day (rather than trading day), we accordingly adjust for the effect of weekends and holidays on our return patterns. The results, omitted for brevity, are virtually identical to those reported in Tables II and III.

\section{Interpretations}

It seems natural to try to link this phenomenon to the information contents in auctions. Although the date and amount of auctions can be almost perfectly anticipated, auction outcomes, such as the bid-to-cover ratio and coupon rate, are likely to be informative signals about the Treasury markets and the overall economic conditions. If the uncertainty about auctions is resolved gradually during the days leading to these auctions, we should expect that the average Treasury returns before auctions be higher than those after. This prediction, however, is opposite to what we find in the data.

A more plausible interpretation is that Treasury auctions exert significant temporary price impacts in secondary Treasury markets. A telltale sign of this interpretation is that there is a strong return reversal in Treasury returns around auctions. For the portfolio examined in Table V, for example, the correlation between the 10-day pre-auction return and the 10-day post-auction return is 0.22 , with a $p$-value 
of 0.002. This implies return reversal in 2-year notes since the strategy is short in the 2year note before auctions, but is long in the 2-year note after auctions.

More precisely, our interpretation has two ingredients. First, primary dealers have limited risk-bearing capacity. In the U.S. Treasury market, primary dealers are expected to participate actively in all auctions and submit meaningful bids. Put differently, primary dealers are expected to acquire large positions in these auctioned securities. Due to limited risk-bearing capacity, the dealers need to hedge this to-beacquired large exposure by shorting similar securities in the secondary Treasury market as well as shorting in the when-issued market. These short-selling activities exert significant downward pressure on secondary market prices. ${ }^{23}$

The second ingredient of our interpretation is that end-investors in Treasury markets are likely constrained from providing liquidity instantly. This point is particularly important since a large amount - relative to auction size - of Treasury securities are also maturing around auctions, indicating that end-investors indeed have enough capital to absorb the supply shock from these auctions. For primary dealers' shorting activities to have any significant price impact, end-investors' capital has to be slow moving. Our interpretation has a number of further implications, which we explore next.

\section{A. Limited risk-bearing capacity}

Primary dealers' limited risk-bearing capacity has the following two additional predictions. First, given the similarities among Treasury notes across maturities, the price pressure resulting from Treasury auctions of one maturity should naturally spill over to Treasury securities with different maturities, and this impact should be stronger if the maturity differential is smaller. Second, the price impact of Treasury auctions should be stronger when the total risk expected to be acquired by primary dealers is higher; for instance, when the auction size is larger and in periods with higher implied Treasury return volatilities.

\footnotetext{
${ }^{23}$ Primary dealers' short selling in the when-issued market can also depress spot Treasury prices, if the counterparties with long positions in the when-issued market hedge their exposure in the secondary Treasury market.
} 
To test the first prediction, we examine the yield patterns of 10-year notes around 2- and 5-year note auctions. We explicitly exclude observations where there is a 10-year note auction within 10 days of a 2- or 5-year note auction, to ensure that we are not picking up the effect of own auctions. ${ }^{24}$ Consistent with our prediction, Table VI shows that an inverted $\mathrm{V}$-shaped yield pattern also arises for 10-year notes around 2- or 5-year note auctions. 10-year note yields increase significantly before both 2- and 5-year note auctions and decrease afterward. Not surprisingly, because of the large difference in maturity between 2-year and 10-year notes, the yield change resulting from 2-year note auctions is small, hovering around one basis point, and is statistically significant in only a few days surrounding auction days. In contrast, 5-year note auctions have a much stronger impact on 10-year yields. The magnitude of the impact is around 3 basis points, and 6 out of the 10 point estimates are significant at the $5 \%$ level.

In testing the second prediction, we conduct a simple time-series regression. The dependent variable is the cumulative return of the long-short portfolio defined in Table $\mathrm{V}$ during the 20-day window around auctions, which is meant to measure the price impact of Treasury auctions. The independent variables include the offering size and Treasury options implied return volatilities, both of which reflect the risk primary dealers are expected to acquire at auctions. We use Mueller, Vedolin, and Yen (2011)'s model-free estimates of maturity-weighted average implied volatilities of nearest-toexpiry at-the-money options on the 30-year, 10-year, and 5-year Treasury securities at the end of the previous month. The results are similar if we use different weights (e.g., equal weights). We also include year fixed effects to de-trend offering size. The results are summarized in Table VII. Consistent with the prediction, we find that the price impact of Treasury auctions is substantially more pronounced when the offering size is larger and when the Treasury market is more volatile. Specifically, as shown in Panel A, the coefficient estimate on offering size is $4.58(t=1.71)$ and that on the implied volatility is $1.68(t=2.28)$. In other words, one-standard-deviation increases in offering

\footnotetext{
${ }^{24}$ This requirement significantly limits our potential choices of combinations. For example, we cannot examine the yield patterns of 2-year notes around auctions of 5- and 10-year note auctions, as there are only a small number of 5- and 10-year note auctions that are not within one week of any 2-year note auction.
} 
size and Treasury options implied volatility lead to $1.79(=4.58 \times 0.39)$ and 2.94 $(=1.68 \times 1.75)$ basis points increases in the long-short portfolio return.

The marginal significance of offering size is likely due to the fact that auctions of other maturities also occur in the vicinity of 2-year note auctions. For instance, in a large part of our sample, there is a 5-year note auction within a few days following each 2-year note auction. Due to the across-maturity spillover effect (Table VI), these 5-year note auctions can mitigate (or sometimes strengthen) the price impact of 2-year note auctions. To better capture the price effect of Treasury auctions of all maturities, we construct a measure of "offering size imbalance," OSI $(t)$, which is defined as the logarithm of the aggregate offering amount from all Treasury note auctions of any maturity during the $t$ days prior to the day in question (i.e., day 0 ) minus that during the $t$ days following day 0 . The idea is that if more Treasury securities are auctioned in the next few days, the price pressure implies a low return today. On the other hand, if more securities are auctioned in the previous a few days, the recovery from that price pressure implies a high return for today. That is, our price pressure interpretation implies a positive coefficient on $\operatorname{OSI}(t)$. To address time variations in expected bond returns, we use the daily 2-year note return minus the average 2-year return in the surrounding 20 days as the dependent variable. ${ }^{25}$ Consistent with our prediction, as shown in Panel B, the coefficients estimates on $O S I(t)$ are significantly positive. For example, the coefficient is $0.029(t=2.79)$ for $\operatorname{OSI}(5)$, and $0.046(t=3.83)$ for $\operatorname{OSI}(10)$. Put differently, an increase in OSI(5) by the average size of a 2-year note auction (i.e., $\$ 20$ billion) is associated with an increase in daily 2-year note returns of 0.69 $(=0.029 \times \log (20 \mathrm{~B}))$ basis points.

Taken together, the evidence lends further support to our hypothesis that, due to limited risk-bearing capacity, primary dealers hedge the risk they are expected to acquire at auctions by short selling similar securities, and thus causing downward price pressure in secondary markets before auctions. In addition, such price impact is more

\footnotetext{
${ }^{25}$ Alternatively, we also use unadjusted daily returns as the dependent variable with and without monthfixed effects. The results remain similar.
} 
pronounced for Treasury securities with closer maturities to those auctioned securities, when the auction amount is larger, and when Treasury markets are more volatile.

\section{B. Slow-moving end-investors}

The second ingredient in our interpretation is end-investors' slow responses to transitory yield changes in the Treasury market. Major investors in Treasury markets are indeed likely to be unresponsive to transient demand/supply shocks. According to data compiled by the Treasury Department, although the total size of the Treasury securities outstanding is around $\$ 10$ trillion toward the end of our sample, over $40 \%$ of them are nonmarketable and held by Federal Government accounts. The Federal Reserve holds another $8 \%$ to $9 \%$ of outstanding Treasury securities, most of which is obtained through noncompetitive bids at auctions. Given the mandates of the Federal Reserve, it is unlikely that either would respond to transient movements in Treasury yields. "Private holdings" account for the rest, of which state and local governments and foreign investors hold more than half. While there are no publicly available data on these investors' trading behavior, it seems reasonable to expect that many of them do not have the intention, or resources, to adjust their positions on a daily basis to exploit the opportunity from transitory price movements.

In addition, we have two pieces of further evidence on the slow responses of two other major investors in Treasury securities. First, insurance companies collectively hold about $\$ 160$ billion of Treasury securities at the end of our sample, which amounts to $3.3 \%$ of the private holdings. We gather data on their trading and holdings from Schedule D of their reports to National Association of Insurance Companies (NAIC). Our analyses suggest that insurance companies trade very infrequently in the Treasury market. For example, close to $70 \%$ of all insurance companies make less than five trades, and in any given year, around $14 \%$ of them do not make any trade. While this finding is consistent with insurance companies' general objective to maintain a low turnover, it suggests that insurance companies are unlikely to absorb sudden supply changes in the Treasury market. 
Second, we also examine the behavior of bond mutual funds. At the end of our sample, bond mutual funds collectively hold close to 500 billion dollars' worth of Treasury securities, which accounts for around $10 \%$ of all private holdings. Index bond mutual funds are likely to avoid newly issued securities due to concerns of tracking errors. Many fixed-income indices usually adjust their composition at the end of each month. As a result, index bond mutual fund managers are likely to be reluctant to purchase the new securities before they are included in the indices they are tracking. In other words, rather than exploiting the yield changes around auctions, index fund might be part of the cause of the phenomenon.

For active bond mutual funds, while we do not directly observe their trading, we gauge their ability to absorb sudden increases in Treasury supply by examining their capital flow patterns around Treasury auctions. Specifically, we obtain a daily series of total net assets and investment returns for three fund classes - bond funds, equity funds, and hybrid funds (which invest in both bonds and equities), from TrimTabs. We then compute the daily investment flow to each fund class in day $t$ as the percentage change in total net assets from $t-1$ to $t$, after adjusting for the investment return in day $t$. Similar to the tests for bond return patterns around auctions, we compare the difference between the cumulative capital flow to each fund class during the $t$ days subsequent to an auction and the cumulative flow during the $t$ days prior to the auction. We focus on 2-year Treasury note auctions in this test since the flow data are not available before 1998 and there are too few observations for other maturities in the post-1998 period.

The results are shown in Table VIII. Columns 1 and 2 present the flow pattern for bond mutual funds around 2-year note auctions. Overall, there are significantly larger capital inflows to bond mutual funds after Treasury auctions than before these auctions. The difference in cumulative capital flows to bond funds keeps drifting upward after the auction day and peaks on days 9 and 10. During the 10 days after a 2-year note auction, the cumulative capital inflow to bond mutual funds is about $16(t=3.02)$ basis points higher than that during the 10 days prior to the auction. For reference, the average daily flow to bond mutual funds in our sample period is only 0.4 basis points each day. The evidence that investors move their capital into bond mutual funds at a 
higher rate after Treasury auctions than before these auctions suggests that mutual fund investors are slow in reallocating their capital across asset classes, perhaps due to limited attention. ${ }^{26}$ Consistent with this view, in further analyses, we find that capital flows to equity and hybrid mutual funds after auctions are generally lower than those before auctions, albeit with marginal statistical significance.

\section{The Impact on Repo Markets}

Our interpretation also implies that auctions may exert a large impact on the repo markets. Recall that, anticipating the large positions that they will assume at auctions, primary dealers would short in the secondary market to hedge the risk. To take short positions, they need to borrow Treasury securities through "reverse repo" transactions, which is essentially primary dealers lending cash to their counterparties and taking Treasury securities as collateral, so they can sell those Treasury securities short. From the perspective of their counterparties, these are repo transactions. Naturally, primary dealers have stronger incentives to initiate these reverse-repo transactions shortly before Treasury auctions than in other periods. As a result, they would be willing to accept lower interest rates in these transactions, leading to lower repo rates before auctions. Moreover, since this hedging activity is expected to last only for a few days, the impact should be stronger for overnight repo rates than for long-term repo rates.

To test this idea, we obtain daily data on overnight, one-week, and one-month repo rates from Bloomberg. Since our prediction is that repo rates decrease before auctions due to the scarcity of Treasury security collaterals, our analysis is focused on general-collateral repo rates, which are the interest rates in repo contracts backed by Government General Collaterals. Since the repo data are available only for the post1992 period, we center our analysis around the most frequent 2-year note auctions for statistical power reasons.

\footnotetext{
${ }^{26}$ The evidence does not pin down how investors are attracted to bond mutual funds after auctions. It could be that investors have more exposure to media coverage about Treasury securities around auctions, which induces them to invest. Alternatively, some institutional investors may prefer to keep a low turnover and adjust their positions infrequently. The higher yields around auctions can only attract these institutional investors slowly over time.
} 
We compare the average repo rates after 2-year note auctions with those before. The results are reported in Table IX. Consistent with our prediction, repo rates in the pre-auction period are significantly lower than those in the post-auction period. For example, as shown in columns 1 and 2, the average overnight repo rate during the 10 days before auctions is, on average, 3.47 basis points lower than during the 10-day period after the auctions, with a $t$-statistic of 2.21 . This rate differential is positive for the entire 20-day window around auction days and reaches its maximum on day 5 , with a point estimate of 6.75 basis points and a t-statistic of 4.83 . There is a similar but slightly weaker pattern in one-week term repo rates (columns 3 and 4). For example, the average 5 -day pre-auction one-week rate is $4.39(t=4.36)$ basis points lower than that during the post-auction 5-day period. This pattern almost completely disappears for one-month term repo rates, for which most of the point estimates are indistinguishable from 0 . These results are consistent with the hypothesis that primary dealers hedge their risk in the a few days before Treasury auctions, and thus drive down short-term repo rates. We also repeat our analysis on reverse repo rates. Since the relationship between repo and reverse repo rates are similar to that between bid and ask prices, the results based on reverse repo rates, omitted for brevity, are almost identical to those based on repo rates.

\section{The Impact on Stock Returns}

More broadly, since Treasury yields are the basis for pricing assets in other financial markets, and given the magnitude of fluctuations in Treasury yields around auctions, one may expect these Treasury auctions to also significantly affect the prices in other markets, such as the U.S. equity market. We examine three market indices: the valueweighted CRSP index, the equal-weighted CRSP index, and the value-weighted S\&P 500 index. For each index, we compute $\Delta C R(t)$, the cumulative market return during the $t$ days after each auction minus that during the $t$ days before the auction. The results are reported in Table X. Columns 1 and 2 present the average of $\Delta C R(t)$ based on the value-weighted CRSP index around 2-year Treasury note auctions. $\Delta C R(t)$ is significantly positive for all $t$ ranging from 4 to 9 , and peaks on day 6. For example, 
$\Delta C R(5)$ is $49(t=3.11)$ basis points; that is, the cumulative CRSP value-weighted market return in the 5 days after a 2-year Treasury note auction is, on average, 49 basis points higher than that during the 5 days before these auctions. This is a substantial difference since the unconditional expected return of the value-weighted CRSP index is 4.45 basis points per day. In other words, the annualized expected return in the 5 days before each auction is $-1.1 \%$, while that based on the 5 days after an auction is $23.4 \%$. This return pattern is similar for equal-weighted CRSP returns, as reported in columns 3 and 4 . Interestingly, this return pattern also arises for the value-weighted S\&P 500 index (columns 5 and 6), suggesting the observed phenomenon is not driven by small stocks only.

The stock return effect documented here is not specific to 2-year note auctions. In unreported analysis, we find a similar stock return pattern around 5-year note auctions. but due to substantial reduction in sample size, the estimate based on 10-year auctions is statistically insignificant. To analyze the price impact resulting from Treasury auctions of all maturities simultaneously, we conduct a similar analysis to that reported in Panel B of Table VII. Specifically, we regress excess daily stock market returns on offering size imbalance. Our results, omitted for brevity, show that stock returns tend to be higher (lower) if more Treasury notes are auctioned in the previous (subsequent) 5 to 10 days.

We also consider a number of alternative explanations for the stock return pattern. First, one might suspect that the higher post-auction returns are compensation for higher volatility. However, we find that stock market returns, based on all three market indices, are slightly more volatile before Treasury auctions than after, thus inconsistent with this hypothesis. In addition, our findings cannot be attributed to previously known calendar-time return effects such as turn-of-the-month and turn-ofthe-year effects. We exclude all Treasury auctions from our analyses that take place between the $25^{\text {th }}$ of a month to the $5^{\text {th }}$ of the following month, or in the first or last month of a year, and the results are very similar.

One possible interpretation of our finding is that the temporary drop in Treasury prices before auctions induces some investors, such as asset allocation mutual funds and 
hedge funds, to move their capital from the equity market to the Treasury market. Such cross-market arbitrage trades can then lead to a temporary price effect in the equity market. While direct tests of this mechanism, which require detailed daily trading data of hedge funds and mutual funds in both markets, are not feasible, we provide some circumstantial evidence consistent with this hypothesis. In unreported analysis, we find that the stock return pattern is substantially stronger among stocks with higher idiosyncratic volatilities, higher effective bid-ask spreads, and higher institutional ownership. While this interpretation is potentially consistent with our findings, the exact underlying mechanism for such a large price impact remains unclear.

\section{Conclusion}

Our empirical evidence suggests that anticipated and frequently repeated supply shocks such as Treasury auctions can have first-order impacts on the secondary Treasury, repo, and equity markets. These results suggest significant issuance costs borne by the Treasury Department, which are an order of magnitude larger than the estimated auction markups in prior literature. For instance, the estimated cost of issuing Treasury notes alone is over half a billion dollars in 2007. Our results further call for theoretical and empirical studies to analyze and improve the efficiency of the Treasury securityselling mechanism in settings in which anticipated supply shocks can affect market prices.

Our results also pose significant challenges to existing asset-pricing theories and suggest that market frictions are playing an important role even in the most liquid and well-developed financial markets. Hence, explicitly modeling the risk-bearing capacity of broker-dealers in financial markets and the slow responses of some classes of large investors might be fruitful directions for future research. 


\section{References}

Acharya, Viral, Hyun-Song Shin, and Tanju Yorulmazer, 2009, A Theory of Slow Moving Capital and Contagion, working paper.

Amihud, Yakov, Haim Mendelson, 1991, Liquidity, maturity, and the yields on U.S. Treasury securities, Journal of Finance 46, 31-53.

Asness, Cliff, Tobias Moskowitz, and Lasse Pedersen, 2008, Value and Momentum Everywhere, working paper.

Bikhchandani S., and Huang, C., Auctions with resale markets: A model of Treasury bill markets, Review of Financial Studies 2, 311-339, 1989.

Brunnermeir, M., Nagel, S. and Pedersen, L., 2009 Carry Trades and Currency Crashes, working paper.

Burnside, Craig, Martin Eichenbaum, Isaac Kleshchelski, and Sergio Rebelo, 2010, Do Peso Problems Explain the Returns to the Carry Trade? Review of Financial Studies, forthcoming.

Coval, Joshua, and Erik Stafford, 2007, Asset fire sales (and purchases) in equity markets, Journal of Financial Economics 86, 479-512.

Duffee, Gregory, 1996, Idiosyncratic variation of Treasury bill yields, Journal of Finance $51,527-552$.

Duffie, Darrell, 2010, Asset Price Dynamics with Slow-Moving Capital, Journal of Finance, forthcoming.

Edelen, R. and Warner, J. 2001, Aggregate price effects of institutional trading: a study of mutual fund flow and market returns, Journal of Financial Economics 59, 195220.

Fleckenstein, Matthias, Francis Longstaff and Hanno Lustig, 2010. Why Does the Treasury Issue TIPS? The TIPS-Treasury Bond Puzzle, working paper.

Fleming, Michael, 2002, Are Larger Issues More Liquid? Evidence from Bill Reopenings, Journal of Money, Credit and Banking, 34, 707-735.

Fleming, Michael, 2003. Measuring Treasury Market Liquidity, FRBNY Economic Policy Review (September) 83-108.

Fleming, Michael, 2007, Who Buys Treasury Securities at Auction? Federal Reserve Bank of New York Current Issues in Economics and Finance 13, no. 1.

Fleming, Michael and Joshua V. Rosenberg, 2007, How do Treasury dealers manage their positions?, working paper.

Frazzini, Andrea, and Owen A. Lamont, 2008, Dumb Money: Mutual Fund Flows and the Cross-Section of Stock Returns, Journal of Financial Economics 88, 299-322.

Garbade, K. and M. Rutherford, 2007, Buybacks in Treasury Cash and Debt Management, Staff Report 304, Federal Reserve Bank of New York. 
Goldreich D., 2007, Underpricing in Discriminatory and Uniform-Price Treasury Auctions, Journal of Financial and Quantitative Analysis, 443-466.

Gorton, Gary and Andrew Metrick, 2010, Securitized Banking and the Run on Repo, working paper.

Greene, J. and Hodges, C., 2002. The dilution impact of daily fund flows on open-end mutual funds. Journal of Financial Economics 65, 131-158.

Greenwood, Robin, 2005, Short and long term demand curves for stocks: Theory and evidence, Journal of Financial Economics 75, 607-650.

Greenwood, Robin and Dimitri Vayanos, 2010a, Bond Supply and Excess Bond Returns, working paper.

Greenwood, Robin and Dimitri Vayanos, 2010b, Price Pressure in the Government Bond Market, American Economic Review, Papers and Proceedings, 585-590.

He, Zhiguo, and Wei Xiong, 2009, Multi-market Delegated Asset Management, working paper.

Jegadeesh, N., 1993, Treasury auction bids and the Salomon squeeze, Journal of Finance 48, 1403-1419.

Jiang, Wenxi, Hongjun Yan, and Tong Yu, 2010, Trading during Financial Crisis: Evidence from Insurance Companies, working paper.

Jin, Jiaqi and Hongjun Yan, 2011, Selling to slow-moving investors, working paper.

Kaul, Aditya, Vikas Mehrotra, and Randall Morck, 2000, Demand curves for stocks do slope down: New evidence from an index weights adjustment, Journal of Finance $55,893-912$.

Krishnamurthy, Arvind, 2002, The Bond/Old-Bond Spread, Journal of Financial Economics, 66, 463-506.

Krishnamurthy, Arvind, and Annette Vissing-Jorgensen, 2010, The Aggregate Demand for Treasury Debt, working paper.

Kuttner, K., 2006, Can Central Banks Target Bond Prices?, working paper 12454, National Bureau of Economic Research.

Lou, Dong, 2010, A flow-based explanation for return predictability, Working paper,

Lustig, Hanno, Nikolai Roussanov, and Adrien Verdelhan, 2009, Common Risk Factors in Currency Markets, working paper.

Malliaris, Steven and Hongjun Yan, 2010, Reputation Concerns and Slow-Moving Capital, working paper

Mitchell, Mark, Lasse Pedersen, and Todd Pulvino, 2007, Slow Moving Capital, American Economic Review, Papers and Proceedings 97, 215-220.

Mitchell, Mark, Todd Pulvino, and Erik Stafford, 2004, Price pressure around mergers, Journal of Finance 59, 31-63. 
Mueller, P., A. Vedolin and Y. Yen, 2011, Bond Variance Risk Premia, working paper.

Nyborg, Kjell and Suresh Sundaresan, 1996, Discriminatory versus Uniform Treasury Auctions: Evidence from When-Issued Transactions, Journal of Financial Economics, 42, 63-104.

Shleifer, Andrei, 1986, Do demand curves for stocks slope down? Journal of Finance 41, 579-590.

Simon, D., 1991, Segmentation in the Treasury Bill Market: Evidence from Cash Management Bills, Journal of Financial and Quantitative Analysis, 26, 97-108.

Simon, D., 1994, Further Evidence on Segmentation in the Treasury Bill Market, Journal of Banking and Finance, 18, 139-151.

Wurgler, Jeffrey, and Ekaterina Zhuravskaya, 2002, Does arbitrage flatten demand curves for stocks? Journal of Business 75, 583-608.

Vayanos, Dimitri and Jean-Luc Vila, 2009, A Preferred-Habitat Model of the TermStructure of Interest Rates, working paper, London School of Economics. 
Table I. Summary Statistics

Panel A reports the summary statistics of Treasury note auctions. Maturity is the number of years to maturity of a Treasury note. Under Auction Type, "Multiple" denotes a multiple-price auction and "Single" denotes a single-price auction. No. of Issues is the total number of issues in our sample. Amount is the face value issued at each auction. Bid-to-Cover Ratio is the ratio of total value bid in an auction to the total face value issued to all competitive bidders. Auction Yield is the maximum winning yield for a single-price auction, and is the weighted-average yield based on the amount issued at each winning yield for a multiple-price auction. Panel B reports the summary statistics for Treasury notes and stocks. daily return is the change in daily price levels including coupon distributions. duration is the modified duration (expressed in years) of the on-the-run security on the subsequent auction day. vwght daily return is the valueweighted portfolio return, and ewght daily return is the equal-weighted portfolio return. The sample period for Panels A and B is January 1980 to June 2008. Panel C reports the summary statistics for other data. Treasury options implied volatility is the modelfree maturity-weighted implied volatility of nearest-to-expiry at-the-money options on the 30-year, 10-year, and 5-year Treasury securities from January 1982 to June 2008. daily flow is the daily percentage flow to mutual funds from January 1998 to June 2008. The sample period for repo rates is from January 1992 to June 2008. Yields, returns, and daily flows are expressed in basis points.

\begin{tabular}{ccccccccc}
\hline \multicolumn{7}{c}{ Panel A: Summary statistics of Treasury auctions (1980-2008) } \\
\hline \multirow{2}{*}{ Maturity } & Auction & No. of & Amount $(\$$ Billions) & Bid-to-Cover Ratio & Auction Yield (\%) \\
\cline { 4 - 9 } & Type & Issues & Mean & Stdev & Mean & Stdev & Mean & Stdev \\
\hline 2 & Multiple & 150 & 10.13 & 3.24 & 2.68 & 0.56 & 9.26 & 2.59 \\
2 & Single & 182 & 22.93 & 6.21 & 2.61 & 0.4 & 5.09 & 1.28 \\
2 & Total & 332 & 17.13 & 8.16 & 2.64 & 0.48 & 6.36 & 2.62 \\
\hline 5 & Multiple & 64 & 7.66 & 2.41 & 2.78 & 0.49 & 8.78 & 2.61 \\
5 & Single & 146 & 14.83 & 2.84 & 2.57 & 0.38 & 4.68 & 0.66 \\
5 & Total & 210 & 12.64 & 4.27 & 2.63 & 0.43 & 7.01 & 2.86 \\
\hline 10 & Multiple & 75 & 9.92 & 3.65 & 2.44 & 0.34 & 7.76 & 3.19 \\
10 & Single & 57 & 13.03 & 4.01 & 2.38 & 0.43 & 5.29 & 0.64 \\
10 & Total & 132 & 11.27 & 4.1 & 2.41 & 0.38 & 7.57 & 3.14 \\
\hline
\end{tabular}




\begin{tabular}{lccccc}
\hline \multicolumn{5}{c}{ Panel B: Summary statistics of Treasury notes and stocks (1980-2008) } \\
\hline Variables & Mean & $\begin{array}{c}\text { Standard } \\
\text { Deviation }\end{array}$ & $25^{\text {th }}$ & Median & $75^{\text {th }}$ \\
\hline Summary statistics of Treasury note returns (basis point) & & & \\
daily return (2-year) & 2.85 & 16.24 & -4.24 & 2.34 & 9.63 \\
daily return (5-year) & 3.33 & 34.48 & -13.65 & 3.08 & 20.58 \\
daily return (10-year) & 3.36 & 49.75 & -23.16 & 3.33 & 30.45 \\
\hline Summary statistics of Treasury note durations (year) & & & \\
duration (2-year) & 1.78 & 0.07 & 1.74 & 1.79 & 1.83 \\
duration (5-year) & 4.16 & 0.27 & 4.04 & 4.19 & 4.34 \\
duration (10-year) & 6.98 & 0.88 & 6.40 & 7.07 & 7.74 \\
\hline Summary statistics of stock returns (basis point) & & & \\
CRSP vwght daily return & 4.45 & 105.70 & -42.39 & 7.71 & 54.01 \\
CRSP ewght daily return & 8.15 & 82.99 & -24.17 & 14.52 & 47.10 \\
SP500 vwght daily return & 3.53 & 111.69 & -48.26 & 4.81 & 56.90 \\
\hline
\end{tabular}

\section{Panel C: Other data}

\begin{tabular}{|c|c|c|c|c|c|}
\hline \multicolumn{6}{|c|}{ Summary statistics of Treasury options implied volatilities (\%) (1982-2008) } \\
\hline Implied Volatility & 8.00 & 1.75 & 6.99 & 7.75 & 8.82 \\
\hline \multicolumn{6}{|c|}{ Summary statistics of daily mutual fund flows (basis point) (1998-2008) } \\
\hline daily flow to bond funds & 0.40 & 15.31 & -3.24 & -0.02 & 3.33 \\
\hline daily flow to equity funds & -0.92 & 10.27 & -5.09 & -1.72 & 1.87 \\
\hline daily flow to hybrid funds & -0.19 & 11.06 & -3.95 & -0.06 & 3.49 \\
\hline \multicolumn{6}{|c|}{ Summary statistics of General Collateral Repo rates (\%) (1992-2008) } \\
\hline overnight & 3.97 & 1.63 & 2.90 & 4.49 & 5.31 \\
\hline one week & 3.96 & 1.63 & 2.92 & 4.53 & 5.30 \\
\hline one month & 3.97 & 1.63 & 2.90 & 4.52 & 5.30 \\
\hline
\end{tabular}


Table II. Treasury Yields Around Subsequent Auctions

This table reports the time-series average of $Y(t)-Y(0)$, which is the yield of an on-therun $n$-year Treasury note $(n=2,5,10)$ on day $t$ (where $t$ ranges from -10 to 10 ) minus the yield of the same note on the day when a subsequent $n$-year note auction is conducted. (More precisely, the note is on-the-run before the auction and becomes off-the-run after the auction.) The sample period is from January 1980 to June 2008. All yields are expressed in basis points. T-statistics are based on standard errors that are Newey-West adjusted up to 12 lags, and are reported in parentheses. ***, **, and * indicate significance levels of $1 \%, 5 \%$, and $10 \%$, respectively.

\begin{tabular}{|c|c|c|c|c|c|c|}
\hline \multicolumn{7}{|c|}{ Treasury yields around subsequent auctions: $Y(t)-Y(0)$} \\
\hline \multirow[b]{2}{*}{$t$} & \multicolumn{2}{|c|}{ 2-year notes } & \multicolumn{2}{|c|}{ 5-year notes } & \multicolumn{2}{|c|}{ 10-year notes } \\
\hline & Mean & $t$-value & Mean & $t$-value & Mean & $t$-value \\
\hline-10 & -1.16 & $(-0.59)$ & $-2.68^{*}$ & $(-1.87)$ & -0.79 & $(-0.39)$ \\
\hline-9 & -1.82 & $(-0.98)$ & -2.50 & $(-1.60)$ & -2.14 & $(-1.21)$ \\
\hline-8 & -2.86 & $(-1.50)$ & $-3.35^{* *}$ & $(-2.43)$ & -1.64 & $(-0.95)$ \\
\hline-7 & $-3.04^{*}$ & $(-1.68)$ & $-2.61 *$ & $(-1.95)$ & -0.10 & $(-0.06)$ \\
\hline-6 & $-2.64^{*}$ & $(-1.83)$ & -2.07 & $(-1.54)$ & -1.03 & $(-0.71)$ \\
\hline-5 & $-2.53^{*}$ & $(-1.50)$ & $-2.67^{* *}$ & $(-2.50)$ & -1.57 & $(-1.11)$ \\
\hline-4 & $-2.81^{*}$ & $(-1.77)$ & $-2.96^{* * *}$ & $(-3.08)$ & $-2.76^{* *}$ & $(-2.02)$ \\
\hline-3 & $-3.01^{* *}$ & $(-2.21)$ & $-1.56^{*}$ & $(-1.80)$ & $-2.25^{* *}$ & $(-2.04)$ \\
\hline-2 & $-2.06^{* *}$ & $(-2.03)$ & -0.64 & $(-1.14)$ & -0.41 & $(-0.52)$ \\
\hline-1 & $-1.77^{* * *}$ & $(-3.18)$ & 0.30 & $(0.67)$ & -0.78 & $(-1.20)$ \\
\hline 1 & -0.36 & $(-1.11)$ & $-0.77^{* *}$ & $(-2.02)$ & -0.56 & $(-1.21)$ \\
\hline 2 & -0.67 & $(-1.09)$ & $-1.74^{* * *}$ & $(-2.88)$ & -1.23 & $(-1.40)$ \\
\hline 3 & -0.87 & $(-0.97)$ & $-2.46^{* * *}$ & $(-2.97)$ & $-1.87^{*}$ & $(-1.70)$ \\
\hline 4 & $-1.92^{*}$ & $(-1.94)$ & $-1.96^{* *}$ & $(-2.37)$ & -2.01 & $(-1.62)$ \\
\hline 5 & $-2.32^{* *}$ & $(-2.18)$ & $-2.74^{* * *}$ & $(-2.63)$ & -2.00 & $(-1.51)$ \\
\hline 6 & $-3.19^{* *}$ & $(-2.61)$ & -2.11 & $(-1.58)$ & -1.48 & $(-1.32)$ \\
\hline 7 & $-2.93^{* *}$ & $(-2.14)$ & -2.75 & $(-1.58)$ & $-2.78^{*}$ & $(-1.70)$ \\
\hline 8 & -2.77 & $(-1.60)$ & $-3.41^{* *}$ & $(-2.10)$ & $-3.42^{*}$ & $(-1.90)$ \\
\hline 9 & $-3.19^{*}$ & $(-1.74)$ & $-3.09^{*}$ & $(-1.95)$ & $-4.47^{* *}$ & $(-2.07)$ \\
\hline 10 & $-3.91^{* *}$ & $(-2.13)$ & $-2.95^{*}$ & $(-1.88)$ & $-4.68^{* *}$ & $(-2.00)$ \\
\hline No. Obs. & \multicolumn{2}{|c|}{332} & \multicolumn{2}{|c|}{210} & \multicolumn{2}{|c|}{132} \\
\hline
\end{tabular}


Table III. Treasury Returns Around Subsequent Auctions

This table reports the time-series average of $\Delta C R(t)$, which is the cumulative return of an on-the-run $n$-year Treasury note $(n=2,5,10)$ during the $t$ days after a subsequent $n$ year note auction minus the cumulative return of the same $n$-year note during the $t$ days before the auction, where $t$ ranges from 1 to 10. (More precisely, the note is on-therun before the auction and becomes off-the-run after the auction.) The sample period is from January 1980 to June 2008. All returns are expressed in basis points. T-statistics are based on standard errors that are Newey-West adjusted up to 12 lags, and are reported in parentheses. ${ }^{* * *}, * *$, and $*$ indicate significance levels of $1 \%, 5 \%$, and $10 \%$, respective.

\begin{tabular}{ccccccc}
\hline \multicolumn{7}{c}{ Treasury note returns around subsequent auctions: $\Delta C R(t)$} \\
\hline \multirow{2}{*}{$t$} & 2-year notes & \multicolumn{2}{c}{5 -year notes } & \multicolumn{2}{c}{ 10-year notes } \\
\cline { 2 - 7 } & Mean & $t$-value & Mean & $t$-value & Mean & $t$-value \\
\hline 1 & $3.68^{* * *}$ & $(3.90)$ & 1.98 & $(0.99)$ & 8.61 & $(1.53)$ \\
2 & $3.54^{* *}$ & $(2.21)$ & $9.94^{* * *}$ & $(4.03)$ & 10.87 & $(1.13)$ \\
3 & $6.15^{* *}$ & $(2.42)$ & $16.86^{* * *}$ & $(4.28)$ & $26.37^{* *}$ & $(2.31)$ \\
4 & $8.66^{* * *}$ & $(2.87)$ & $20.86^{* * *}$ & $(4.34)$ & $31.61^{* * *}$ & $(2.75)$ \\
5 & $8.89^{* * *}$ & $(2.69)$ & $22.54^{* * *}$ & $(3.67)$ & $23.84^{*}$ & $(1.78)$ \\
6 & $10.20^{* * *}$ & $(3.62)$ & $17.12^{* *}$ & $(2.07)$ & 16.44 & $(1.31)$ \\
7 & $9.42^{* * *}$ & $(2.63)$ & $21.21^{* *}$ & $(2.20)$ & 17.44 & $(1.01)$ \\
8 & $9.61^{* *}$ & $(2.28)$ & $27.59^{* * *}$ & $(3.01)$ & $30.4^{*}$ & $(1.67)$ \\
9 & $9.08^{* *}$ & $(2.23)$ & $22.85^{* *}$ & $(2.43)$ & $40.68^{* *}$ & $(2.02)$ \\
10 & $9.20^{* *}$ & $(2.02)$ & $22.77^{* *}$ & $(2.53)$ & 32.45 & $(1.39)$ \\
No. Obs. & \multicolumn{7}{c}{210} & & 132 \\
\hline \multicolumn{7}{c}{332} \\
\hline
\end{tabular}


Table IV. Costs of Issuing Treasury Notes

Panel A of this table presents the time-series average of $Y(A)-\bar{Y}(t)$, where $Y(A)$ is the auction yield of the newly issued Treasury notes, and $\bar{Y}(t)$ is the average of the yield of the on-the-run $n$-year note $(n=2,5,10)$ on day $t$ before the subsequent auction and the yield of the same note on day $t$ after the auction, with $t$ ranging from 1 to 10. (More precisely, the note is on-the-run before the auction and becomes off-the-run after the auction.) The auction yield is the maximum winning yield for single-price auctions, and is the weighted-average yield based on the amount issued at each winning yield for multiple-price auctions. The sample period is from January 1980 to June 2008. Yields are expressed in basis points. Panel B of this table presents the estimated cost of issuing Treasury notes. The percentage cost is calculated as the product of $Y(A)-\bar{Y}(t)$ and the duration of the notes and is expressed in basis points. The dollar amount cost is based on the Treasury securities issuance in 2007, the last full year in our sample, and is expressed in millions. T-statistics based on standard errors that are Newey-West adjusted up to 12 lags, are reported in parentheses. ***, **, and * indicate significance levels of $1 \%, 5 \%$, and $10 \%$, respectively.

\begin{tabular}{ccccccc}
\hline \multicolumn{7}{c}{ Panel A: Yield difference $Y(A)-\bar{Y}(t)$} \\
\hline \multirow{2}{*}{$t$} & \multicolumn{2}{c}{ 2-year notes } & \multicolumn{2}{c}{5 -year notes } & \multicolumn{2}{c}{ 10-year notes } \\
\cline { 2 - 7 } & Mean & $t$-value & Mean & $t$-value & Mean & $t$-value \\
\hline 1 & $3.63^{* * *}$ & $(5.77)$ & $1.58^{* *}$ & $(2.63)$ & $1.36^{*}$ & $(1.84)$ \\
2 & $3.90^{* * *}$ & $(5.40)$ & $2.52^{* * *}$ & $(3.65)$ & 1.52 & $(1.58)$ \\
3 & $4.50^{* * *}$ & $(5.07)$ & $3.42^{* * *}$ & $(4.36)$ & $2.84^{* *}$ & $(2.26)$ \\
4 & $4.84^{* * *}$ & $(4.88)$ & $3.86^{* * *}$ & $(4.52)$ & $3.19^{* * *}$ & $(3.13)$ \\
5 & $4.90^{* * *}$ & $(4.62)$ & $4.04^{* * *}$ & $(4.70)$ & $2.66^{* * *}$ & $(3.12)$ \\
6 & $5.33^{* * *}$ & $(5.98)$ & $3.44^{* * *}$ & $(3.34)$ & $2.21^{* *}$ & $(2.34)$ \\
7 & $5.42^{* * *}$ & $(5.17)$ & $3.95^{* * *}$ & $(3.01)$ & $2.43^{*}$ & $(1.65)$ \\
8 & $5.38^{* * *}$ & $(4.18)$ & $4.69^{* * *}$ & $(3.82)$ & $3.59^{*}$ & $(1.90)$ \\
9 & $5.03^{* * *}$ & $(3.82)$ & $4.06^{* * *}$ & $(3.41)$ & $4.39^{* *}$ & $(2.07)$ \\
10 & $5.05^{* * *}$ & $(3.42)$ & $4.05^{* * *}$ & $(3.59)$ & $3.85^{*}$ & $(1.71)$ \\
No. Obs. & \multicolumn{7}{c}{332} & \multicolumn{3}{c}{210} & & 132 \\
\hline \multicolumn{7}{c}{}
\end{tabular}




\begin{tabular}{cccccccc}
\hline \multicolumn{6}{c}{ Panel B: Costs of issuance based on the average yield on days - $t$ and $t$} \\
\hline \multirow{2}{*}{$t$} & \multicolumn{2}{c}{ 2-year notes } & \multicolumn{2}{c}{5 -year notes } & 10-year notes & All notes \\
\cline { 2 - 7 } & $\begin{array}{c}\text { Percentage } \\
\text { (basis points) }\end{array}$ & $\begin{array}{c}\text { Amount } \\
\text { (Millions) }\end{array}$ & $\begin{array}{c}\text { Percentage } \\
\text { (basis points) }\end{array}$ & $\begin{array}{c}\text { Amount } \\
\text { (Millions) }\end{array}$ & $\begin{array}{c}\text { Percentage } \\
\text { (basis points) }\end{array}$ & $\begin{array}{c}\text { Amount } \\
\text { (Millions) }\end{array}$ & $\begin{array}{c}\text { Amount } \\
\text { (Millions) }\end{array}$ \\
\hline 1 & 6.72 & 172 & 6.57 & 103 & 9.42 & 79 & 354 \\
2 & 7.22 & 185 & 10.48 & 164 & 10.53 & 88 & 437 \\
3 & 8.33 & 213 & 14.23 & 222 & 19.68 & 165 & 600 \\
4 & 8.95 & 229 & 16.06 & 251 & 22.11 & 186 & 665 \\
5 & 9.07 & 232 & 16.81 & 262 & 18.43 & 155 & 649 \\
6 & 9.86 & 252 & 14.31 & 223 & 15.32 & 129 & 604 \\
7 & 10.03 & 257 & 16.43 & 256 & 16.84 & 141 & 654 \\
8 & 9.95 & 255 & 19.51 & 304 & 24.88 & 209 & 768 \\
9 & 9.31 & 238 & 16.89 & 263 & 30.42 & 256 & 757 \\
10 & 9.34 & 239 & 16.85 & 263 & 26.68 & 224 & 726 \\
\hline
\end{tabular}


Table V. Hedge Portfolio Returns

This table presents $H \operatorname{Ret}(t)$, the cumulative return to a hedge strategy from $t$ days before an auction to $t$ days after, where $t$ ranges from 1 to 10 . On the $t^{\text {th }}$ day before each auction, we construct a hedge portfolio by going short in the on-the-run 2-year note, and going long in a duration-matched portfolio of the on-the-run 6-month T-bill and 10-year note. We hold this hedge portfolio until the auction day, and then reverse our positions: We now go long in the same 2-year note (which just becomes the first offthe-run note) and go short in the duration-matched portfolio of the on-the-run 6-month T-bill and on-the-run 10-year note. We hold this portfolio until the $t^{\text {th }}$ day after the auction. The full sample period is from January 1980 to June 2008. Returns are expressed in basis points. Sharpe Ratio is the annualized Sharpe ratio for this trading strategy. T-statistics based on standard errors that are Newey-West adjusted up to 12 lags, and are reported in parentheses. ***, **, and * indicate significance levels of $1 \%$, $5 \%$, and $10 \%$, respectively.

\begin{tabular}{cccc}
\hline $\begin{array}{c}\text { Panel A: Hedge portfolio returns } H \operatorname{Ret}(t) \\
\text { in the full sample (1980-2008) }\end{array}$ \\
\hline$t$ & Mean & t-value & Sharpe Ratio \\
\hline 1 & $1.04^{*}$ & $(1.67)$ & 0.34 \\
2 & $2.40^{* * *}$ & $(2.89)$ & 0.66 \\
3 & $4.41^{* * *}$ & $(3.35)$ & 0.94 \\
4 & $4.96^{* * *}$ & $(3.30)$ & 0.98 \\
5 & $5.87^{* * *}$ & $(3.10)$ & 0.95 \\
6 & $6.39^{* * *}$ & $(3.95)$ & 1.05 \\
7 & $8.17^{* * *}$ & $(4.00)$ & 1.20 \\
8 & $8.10^{* * *}$ & $(3.88)$ & 1.12 \\
9 & $8.24^{* * *}$ & $(3.60)$ & 1.08 \\
10 & $8.62^{* * *}$ & $(3.65)$ & 1.08 \\
No. Obs & \multicolumn{3}{c}{319} \\
\hline
\end{tabular}

\begin{tabular}{cccc}
\hline \multirow{4}{*}{$\begin{array}{c}\text { Panel B: Hedge portfolio returns HRet }(t) \\
\text { in the period of 1998-2008 }\end{array}$} \\
\hline$t$ & Mean & $t$-value & Sharpe Ratio \\
\hline 1 & -0.40 & $(-0.47)$ & -0.14 \\
2 & 1.37 & $(1.60)$ & 0.50 \\
3 & $2.61^{* * *}$ & $(2.68)$ & 0.84 \\
4 & $4.15^{* * *}$ & $(4.01)$ & 1.05 \\
5 & $4.78^{* * *}$ & $(3.48)$ & 1.06 \\
6 & $6.85^{* * *}$ & $(4.66)$ & 1.32 \\
7 & $8.02^{* * *}$ & $(5.14)$ & 1.56 \\
8 & $7.62^{* * *}$ & $(4.64)$ & 1.41 \\
9 & $8.13^{* * *}$ & $(5.08)$ & 1.44 \\
10 & $8.52^{* * *}$ & $(4.95)$ & 1.44 \\
No. Obs & \multicolumn{3}{c}{116} \\
\hline \multicolumn{3}{c}{}
\end{tabular}


Table VI. On-the-Run 10-Year Treasury Yields Around 2- and 5-Year Auctions This table reports the time-series average of $Y(t)-Y(0)$, which is the yield of an on-therun 10-year Treasury note on day $t$ (where $t$ ranges from -5 to 5 ) minus the yield of the same note on the day when a subsequent $n$-year note $(n=2,5)$ auction is conducted. (More precisely, the note is on-the-run before the auction and becomes off-the-run after the auction.) We exclude 2- and 5- year note auctions that are within one week of any 10-year note auction. The sample period is from January 1980 to June 2008. All yields are expressed in basis points. T-statistics based on standard errors that are Newey-West adjusted up to 12 lags, and are reported in parentheses. ***, **, and * indicate significance levels of $1 \%, 5 \%$, and $10 \%$, respectively.

\begin{tabular}{|c|c|c|c|c|}
\hline \multicolumn{5}{|c|}{ 10-year Treasury yields around 2- and 5-year note auctions: $Y(t)-Y(0)$} \\
\hline \multirow[b]{2}{*}{$t$} & \multicolumn{2}{|c|}{ around 2-year note auctions } & \multicolumn{2}{|c|}{ around 5-year note auctions } \\
\hline & Mean & $t$-value & Mean & $t$-value \\
\hline-5 & -1.48 & $(-1.50)$ & $-2.71^{* *}$ & $(-2.26)$ \\
\hline-4 & -1.44 & $(-1.61)$ & $-2.89^{* *}$ & $(-2.51)$ \\
\hline-3 & $-1.41^{*}$ & $(-1.72)$ & -1.57 & $(-1.60)$ \\
\hline-2 & -0.96 & $(-1.63)$ & -0.69 & $(-1.00)$ \\
\hline-1 & $-1.20 * * *$ & $(-2.70)$ & 0.01 & $(0.01)$ \\
\hline 1 & $-0.74^{*}$ & $(-1.93)$ & -0.22 & $(-0.42)$ \\
\hline 2 & -0.44 & $(-0.67)$ & $-2.12^{* * *}$ & $(-2.98)$ \\
\hline 3 & 0.23 & $(0.22)$ & $-3.08 * * *$ & $(-4.18)$ \\
\hline 4 & -0.68 & $(-0.60)$ & $-2.31 * * *$ & $(-2.90)$ \\
\hline 5 & -0.8 & $(-0.61)$ & $-3.22^{* * *}$ & $(-3.00)$ \\
\hline No. Obs. & \multicolumn{2}{|c|}{275} & \multicolumn{2}{|c|}{144} \\
\hline
\end{tabular}


Table VII. The Effect of Dealers' Risk-Bearing Capacity and Auction Size This table presents the effect of dealers' risk-bearing capacity and auction size on Treasury security returns around subsequent auctions. The dependent variable in Panel A, HRet(10), is described in Table V. Offering Amount is the logarithm of the amount in dollars offered by the Treasury Department in the 2-year note auction. Implied Volatility is the model-free maturity-weighted implied volatility of nearest-to-expiry atthe-money options on the 30-year, 10-year, and 5-year Treasury securities at the end of the previous month. The dependent variable in Panel B is the daily return of on-the-run 2-year Treasury notes, adjusted by the average daily return in the 20-day windows surrounding it. $O S I(t)$ is the logarithm of the aggregate offering amount from all Treasury note auctions of any maturity type during the $t$ days prior to the return date minus that during the $t$ days subsequent to the return date. The sample period is January 1982 to June 2008 for Panel A and is January 1980 to June 2008 Panel B. Tstatistics based on standard errors that are Newey-West adjusted up to 12 lags, and are reported in parentheses. ${ }^{* * *}, * *$, and * indicate significance levels of $1 \%, 5 \%$, and $10 \%$, respectively.

\begin{tabular}{lcc}
\hline \multicolumn{3}{c}{ Panel A: Dependent Variable $=$ HRet $(10)$} \\
\hline Coefficient $\left({ }^{*} 10000\right)$ & $t$-value \\
\hline Implied Volatility & $4.58^{*}$ & $(1.71)$ \\
\hline
\end{tabular}

\begin{tabular}{|c|c|c|}
\hline \multicolumn{3}{|c|}{ Panel B: Dependent Variable = daily 2-year note return } \\
\hline & Coefficient $(* 10000)$ & $t$-value \\
\hline \multicolumn{3}{|c|}{ Dependent Variable $=$ daily 2 -year note return } \\
\hline OSI (5) & $0.029^{* * *}$ & $(2.79)$ \\
\hline \multicolumn{3}{|c|}{ Dependent Variable $=$ daily 2 -year note return } \\
\hline OSI (10) & $0.046^{* * *}$ & $(3.83)$ \\
\hline
\end{tabular}


Table VIII. Daily Mutual Fund Flows Around Treasury Auctions

This table reports the time-series average of $\Delta F L O W(t)$, which is the cumulative daily investment flows during the $t$ days subsequent to a 2-year Treasury note auction minus that during the $t$ days prior to the auction, where $t$ ranges from 1 to 10. The sample period is from January 1998 to June 2008. We examine capital flows to three types of mutual funds: bond mutual funds, equity mutual funds, and hybrid mutual funds. Tstatistics based on standard errors that are Newey-West adjusted up to 12 lags, and are reported in parentheses. ${ }^{* * *},{ }^{* *}$, and * indicate significance levels of $1 \%, 5 \%$, and $10 \%$, respectively.

\begin{tabular}{ccccccc}
\hline \multicolumn{6}{c}{ Mutual fund flows around 2 -year Treasury note auctions: $\Delta F L O W(t)$} \\
\hline \multirow{2}{c}{ bond funds } & \multicolumn{2}{c}{ equity funds } & \multicolumn{2}{c}{ hybrid funds } \\
\cline { 2 - 7 } 1 & Mean & $t$-value & Mean & $t$-value & Mean & $t$-value \\
\hline 2 & $-0.03 \%^{* *}$ & $(-2.22)$ & $0.00 \%$ & $(-0.37)$ & $-0.03 \% * * *$ & $(-2.60)$ \\
3 & $-0.02 \%$ & $(-1.11)$ & $0.01 \%$ & $(0.52)$ & $-0.02 \%$ & $(-1.58)$ \\
4 & $0.03 \%^{* *}$ & $(2.03)$ & $-0.01 \%$ & $(-0.32)$ & $-0.02 \%$ & $(-1.21)$ \\
5 & $0.05 \%^{* * *}$ & $(3.01)$ & $-0.01 \%$ & $(-0.55)$ & $-0.01 \%$ & $(-0.73)$ \\
6 & $0.06 \%^{* * *}$ & $(3.06)$ & $-0.02 \%$ & $(-0.84)$ & $-0.03 \%$ & $(-1.32)$ \\
7 & $0.14 \%^{* * *}$ & $(2.82)$ & $-0.03 \%$ & $(-1.30)$ & $-0.05 \% *$ & $(-1.86)$ \\
8 & $0.15 \%^{* * *}$ & $(2.87)$ & $-0.03 \%$ & $(-1.05)$ & $-0.05 \% *$ & $(-1.81)$ \\
9 & $0.15 \%^{* * *}$ & $(2.95)$ & $-0.02 \%$ & $(-0.89)$ & $-0.05 \% *$ & $(-1.74)$ \\
10 & $0.16 \%^{* * *}$ & $(3.15)$ & $-0.03 \%$ & $(-1.05)$ & $-0.04 \%$ & $(-1.14)$ \\
No. Obs. & $0.16 \%^{* * *}$ & $(3.02)$ & $-0.04 \%$ & $(-1.29)$ & $-0.09 \% * *$ & $(-2.16)$ \\
\hline
\end{tabular}


Table IX. Repo Rates Around Treasury Auctions

This table reports the time-series average of $\Delta \operatorname{Repo}(t)$, which is the average repo rate during the $t$ days subsequent to a 2-year Treasury note auction minus that during the $t$ days prior to the auction, where $t$ ranges from 1 to 10 . The sample period is from January 1992 to June 2008. All repo contracts are backed by Government General Collaterals. Repo rates are expressed in basis points. T-statistics based on standard errors that are Newey-West adjusted up to 12 lags, and are reported in parentheses. ***, $* *$, and $*$ indicate significance levels of $1 \%, 5 \%$, and $10 \%$, respectively.

\begin{tabular}{ccccccc}
\hline \multicolumn{7}{c}{ Average repo rate around auctions: $\Delta R e p o(t)$} \\
\hline \multirow{2}{*}{$t$} & \multicolumn{2}{c}{ Overnight } & \multicolumn{2}{c}{ One-week } & \multicolumn{2}{c}{ One-month } \\
\cline { 2 - 7 } & Mean & $t$-value & Mean & $t$-value & Mean & $t$-value \\
\hline 1 & 1.38 & $(0.99)$ & 1.33 & $(1.50)$ & $-0.70^{*}$ & $(-1.65)$ \\
2 & $3.69^{* *}$ & $(2.39)$ & $2.43^{* * *}$ & $(2.72)$ & 0.11 & $(0.27)$ \\
3 & $5.09^{* * *}$ & $(3.29)$ & $3.78^{* * *}$ & $(3.84)$ & 0.78 & $(1.62)$ \\
4 & $6.53^{* * *}$ & $(4.53)$ & $4.47^{* * *}$ & $(4.31)$ & $1.11^{*}$ & $(1.78)$ \\
5 & $6.75^{* * *}$ & $(4.83)$ & $4.39^{* * *}$ & $(4.36)$ & $1.41^{* *}$ & $(2.03)$ \\
6 & $6.50^{* * *}$ & $(4.67)$ & $3.94^{* * *}$ & $(3.80)$ & 1.08 & $(1.30)$ \\
7 & $5.85^{* * *}$ & $(4.26)$ & $3.41^{* * *}$ & $(3.22)$ & 0.81 & $(0.86)$ \\
8 & $4.85^{* * *}$ & $(3.49)$ & $2.78^{* *}$ & $(2.28)$ & 0.43 & $(0.37)$ \\
9 & $4.13^{* * *}$ & $(2.79)$ & 2.19 & $(1.59)$ & 0.11 & $(0.08)$ \\
10 & $3.47^{* *}$ & $(2.21)$ & 1.68 & $(1.10)$ & -0.19 & $(-0.12)$ \\
No. Obs. & \multicolumn{7}{c}{198} & & & & 198 & \\
\hline
\end{tabular}


Table X. Stock Market Returns Around Treasury Auctions

This table reports the time-series average of $\Delta C R(t)$, which is the cumulative return of the stock market during the $t$ days after a 2-year Treasury note auction minus the cumulative return of the stock market during the $t$ days before the auction, where $t$ ranges from 1 to 10. Three types of market returns are examined here: the valueweighted CRSP return, equal-weighted CRSP return, and value-weighted S\&P500 index return. The sample period is from January 1980 to June 2008. All returns are expressed in basis points. T-statistics based on standard errors that are Newey-West adjusted up to 12 lags, and are reported in parentheses. ${ }^{* * *},{ }^{* *}$, and $*$ indicate significance levels of $1 \%, 5 \%$, and $10 \%$, respectively.

\begin{tabular}{|c|c|c|c|c|c|c|}
\hline \multicolumn{7}{|c|}{ Stock market returns around 2-year note auctions: $\Delta C R(t)$} \\
\hline \multirow[b]{2}{*}{$t$} & \multicolumn{2}{|c|}{ value-weighted CRSP } & \multicolumn{2}{|c|}{ equal-weighted CRSP } & \multicolumn{2}{|c|}{ value-weighted S\&P500 } \\
\hline & Mean & $t$-value & Mean & $t$-value & Mean & $t$-value \\
\hline 1 & $-0.07 \%$ & $(-0.90)$ & $0.04 \%$ & $(0.70)$ & $-0.10 \%$ & $(-1.17)$ \\
\hline 2 & $0.03 \%$ & $(0.33)$ & $0.35 \% * * *$ & $(4.93)$ & $-0.06 \%$ & $(-0.49)$ \\
\hline 3 & $0.16 \%$ & $(1.27)$ & $0.44 \% * * *$ & $(4.88)$ & $0.07 \%$ & $(0.54)$ \\
\hline 4 & $0.33 \% * *$ & $(2.35)$ & $0.39 \% * * *$ & $(3.69)$ & $0.28 \% *$ & $(1.86)$ \\
\hline 5 & $0.49 \% * * *$ & $(3.11)$ & $0.50 \% * * *$ & $(4.04)$ & $0.41 \% * *$ & $(2.50)$ \\
\hline 6 & $0.52 \% * * *$ & $(3.03)$ & $0.65 \% * * *$ & $(4.71)$ & $0.40 \% * *$ & $(2.28)$ \\
\hline 7 & $0.48 \% * * *$ & $(2.57)$ & $0.79 \% * * *$ & $(5.14)$ & $0.32 \%^{*}$ & $(1.68)$ \\
\hline 8 & $0.46 \% * *$ & $(2.31)$ & $0.73 \% * * *$ & $(4.19)$ & $0.30 \%$ & $(1.49)$ \\
\hline 9 & $0.45 \% * *$ & $(2.19)$ & $0.65 \% * * *$ & $(3.52)$ & $0.31 \%$ & $(1.46)$ \\
\hline 10 & $0.29 \%$ & $(1.30)$ & $0.55 \% * * *$ & $(2.71)$ & $0.13 \%$ & $(0.57)$ \\
\hline No. Obs. & \multicolumn{2}{|c|}{332} & \multicolumn{2}{|c|}{332} & \multicolumn{2}{|c|}{332} \\
\hline
\end{tabular}


Figure 1. Treasury Yields Around Auctions

Solid lines in these figures correspond to the time-series average of $Y(t)-Y(0)$, which is the yield of the $n$-year Treasury note $(n=2,5,10)$ on day $t$ (where $t$ ranges from -5 to 5 ) minus the yield of the same note on the day when a subsequent $n$-year note auction is conducted. (More precisely, the note is on-the-run before the auction and becomes offthe-run after the auction.) The dotted lines are the $95 \%$ confidence interval. The top three figures are for on-the-run Treasury notes, and the bottom three figures are for the first off-the-run notes. The sample period is from January 1980 to June 2008. All yields are expressed in basis points.
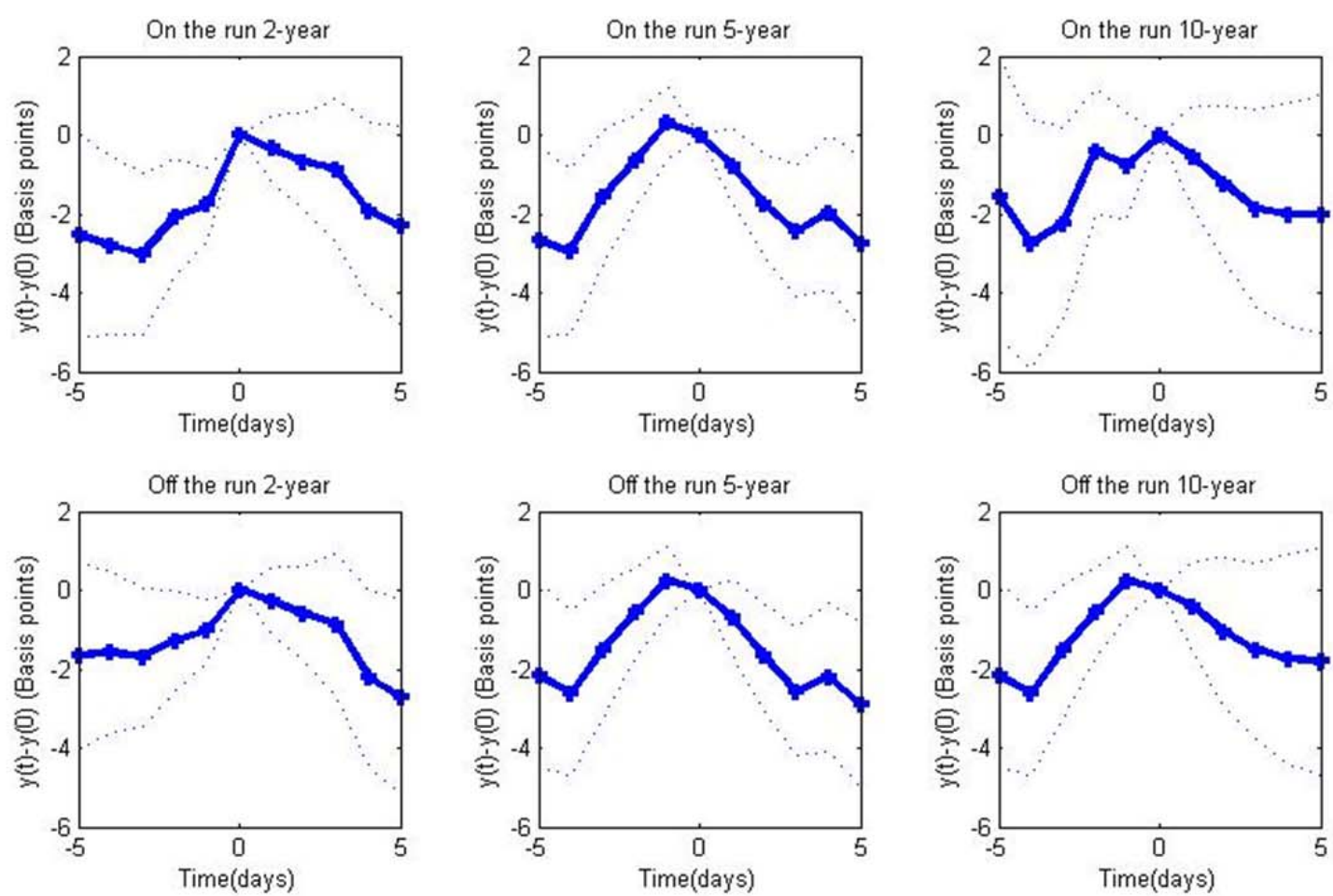